\title{
Advantages of Tyrosine Kinase Anti-Angiogenic Cediranib Over Bevacizumab: Cell Cycle Abrogation and Synergy With Chemotherapy
}

Jianling Bi

The University of lowa Roy J and Lucille A Carver College of Medicine

Garima Dixit

The University of lowa

Yuping Zhang

The University of lowa

Eric J Devor

The University of lowa

Haley A Losh

The University of lowa

Andreea M Newtson

The University of lowa

Kristen L Coleman

The University of lowa

Donna A Santillan

The University of lowa

Thorsten Maretzky

The University of lowa

Kristina W Thiel ( $\square$ kristina-thiel@uiowa.edu )

The University of lowa https://orcid.org/0000-0001-8295-864X

Kimberly K Leslie

The University of lowa

\section{Research}

Keywords: endometrial cancer, bevacizumab, cediranib, patient-derived organoid models, 3D culture, personalized medicine, p53

Posted Date: February 11th, 2021

DOl: https://doi.org/10.21203/rs.3.rs-179830/v1 
License: (c) (i) This work is licensed under a Creative Commons Attribution 4.0 International License. Read Full License 


\section{Abstract}

Background: Angiogenesis plays a crucial role in tumor development and metastasis, and several clinical trials of anti-angiogenic agents have been conducted in advanced and recurrent endometrial cancer. Both bevacizumab and cediranib have demonstrated activity as single agents, though subsequent studies of bevacizumab combined with chemotherapy failed to improve outcomes compared to chemotherapy alone. Our group has previously established that chemotherapy plus an angiokinase inhibitor promotes catastrophic cell death in a xenograft model of endometrial cancer. Our objective was to compare the efficacy of cediranib and bevacizumab in endometrial cancer models.

Methods: The cellular effects of the bevacizumab and cediranib were examined in endometrial cancer cell lines using ERK phosphorylation, ligand shedding, cell viability and cell cycle progression as readouts. Cellular viability following exposure to bevacizumab or cediranib as single agents or in combination with chemotherapy was also tested in eight patient-derived organoid models of endometrial cancer. Finally, we performed a phosphoproteomic array of 875 phosphoproteins to define the signaling changes related to bevacizumab versus cediranib.

Results: Whereas both bevacizumab and cediranib effectively blunted tyrosine kinase receptor signaling in human vascular endothelial cells, only cediranib blocked ligand-mediated ERK activation in endometrial cancer cells. In both cell lines and patient-derived organoid cultures, neither bevacizumab nor cediranib alone had a notable effect on cell viability, even at 1-10 $\mu \mathrm{M}$ concentrations. By contrast, cediranib but not bevacizumab promoted marked cell death when combined with chemotherapy. Cell cycle analysis demonstrated an accumulation in mitosis after treatment with cediranib+chemotherapy, consistent with abrogation of the G2/M checkpoint and subsequent mitotic catastrophe. Molecular analysis of key controllers of the G2/M cell cycle checkpoint confirmed its abrogation. Phosphoproteomic analysis revealed that bevacizumab and cediranib had both similar and unique effects on cell signaling that underlie their shared versus individual actions as anti-angiogenic agents.

Conclusions: Based on these data, we conclude that an anti-angiogenic tyrosine kinase inhibitor such as cediranib has the potential to be superior to bevacizumab in combination with chemotherapy. These data set the stage for future clinical studies of the combination of standard chemotherapy with cediranib in advanced and recurrent endometrial cancer.

\section{Background}

Endometrial carcinoma is the most common gynecologic malignancy in the United States. In 2020, over 65,000 women were diagnosed with endometrial cancer and nearly 13,000 women died of this disease [1]. Although the 5-year survival rate of patients with early-stage endometrial cancer is relatively high, patients with advanced or recurrent endometrial cancer have a poor prognosis. Additionally, population studies have shown that endometrial adenocarcinoma is one of the only cancers in which prevalence and mortality are increasing [2]. Recent progress has been made in defining the molecular biology of 
endometrial carcinoma, which has led to the use of targeted agents to treat this disease. The addition of targeted therapies including anti-angiogenics in conjunction with chemotherapy may be more effective than chemotherapy alone, as we have recently reported (Leslie et al., accepted for publication by Gynecologic Oncology on Jan. 20, 2021; ePub not yet available).

The Gynecologic Oncology Group (GOG, now NRG Oncology) has evaluated a series of anti-angiogenic agents in recurrent endometrial carcinoma. Bevacizumab (Avastin ${ }^{\circledR}$, Genentech) is a recombinant humanized antibody against vascular endothelial growth factor-A (VEGF-A), and it has been studied as a single agent in women with recurrent endometrial cancer in study protocol GOG-229E [3]. From this study, bevacizumab significantly improved PFS compared to additional treatment with chemotherapy [3]. GOG229G, a Phase II trial of combination bevacizumab and temsirolimus (an mTOR inhibitor) was also deemed active in the treatment of recurrent endometrial carcinoma; however, the combination showed significant toxicity [4].

Cediranib is a small molecule multi-tyrosine kinase receptor inhibitor that targets VEGF receptors (VEGFR1/2/3), platelet-derived growth factor receptors (PDGFRa/ $\beta$ and c-Kit) and fibroblast growth factor receptor (FGFR1) [5, 6]. GOG-229J was a study of cediranib as monotherapy in advanced endometrial carcinoma that, like bevacizumab, met the criteria for being considered an active agent in advanced endometrial cancer [7]. It was also found to be tolerable when administered as a single agent [7]. Other anti-angiogenic agents have also been investigated, but they have shown limited activity as single agents in unselected patients [8-11]. The GOG-86P trial of bevacizumab with chemotherapy in patients with advanced endometrial carcinoma did not show a statistically significantly increased PFS relative to historical controls when patients were analyzed as an entire cohort [12].

Preclinical studies have clearly demonstrated activity of single-agent bevacizumab on a variety of tumor models, including endometrial carcinoma. In an orthotopic mouse model of endometrial cancer, bevacizumab significantly reduces tumor volume compared to control [13]. A previous study by our group also showed that bevacizumab inhibits growth of endometrial cancer in a mouse xenograft model [14]. Anti-tumor activity of cediranib has been demonstrated in tumor xenograft models of various types of cancers including colon, lung, prostate, breast, and ovarian cancer $[5,6,15]$. In addition, cediranib decreases tumor vessel density and promotes vascular regression [5].

The vast majority of studies of antiangiogenic agents in endometrial cancer have focused on the inhibitory effects on the tumor vasculature. We hypothesized that therapeutic efficacy could also be derived from effects on the tumor cells. To date, cediranib has not been studied in combination with chemotherapy in endometrial cancer despite the documentation from GOG0229J that it has single agent activity. The studies reported herein were designed to compare the impact of cediranib to bevacizumab to assess whether cediranib may also be effective as an anti-angiogenic and as an adjuvant to chemotherapy. Hence, we compared the efficacy of the two most active anti-angiogenic agents in endometrial cancer, bevacizumab and cediranib, on tumor cell survival and signaling. 


\section{Methods}

\section{Chemicals}

Gefinitib, cediranib, bevacizumab and paclitaxel were purchased from Selleck Chemicals, LLC (Houston, Texas, USA) and suspended in DMSO.

\section{Patient-derived organoid models of endometrial cancer}

All studies using human tissues have been approved by the University of lowa Institutional Review Board (IRB), protocol \#201809807. Patient tumor specimens were obtained within 30 min of surgical resection. Organoids were created per our protocol for ascites fluid [16], with modifications to digest tissue and isolate single cells. Specifically, freshly resected tissue was washed with $10 \mathrm{ml}$ PBS and cut into small pieces. The minced fragments were collected in a $50 \mathrm{ml}$ tube and digested in $5 \mathrm{ml}$ AdDF+++ media (Advanced DMEM-F12 with1X Glutamax,10mM HEPES and Pen strep) supplemented with 2U/ml Dispase $\nabla, 1 \mathrm{mg} / \mathrm{ml}$ collagenase $P$ and $50 \mu \mathrm{g} / \mathrm{ml}$ Dnase I, then incubated at $37^{\circ} \mathrm{C}$ for $0.5-1 \mathrm{~h}$. Dissociated cells were filtered through a $40 \mu \mathrm{m}$ cell strainer, centrifuged at $300 \times \mathrm{g}$ for $10 \mathrm{~min}$, washed twice with PBS and pelleted. Erythrocytes were removed by incubating the dissociated cells with $2 \mathrm{ml}$ red blood cell lysis buffer for $5 \mathrm{~min}$ at room temperature followed by an additional wash with $10 \mathrm{ml} \mathrm{AdDF+++} \mathrm{and}$ centrifugation at $300 \times g$ for 5 minutes. Finally, the cells were counted and embedded in Matrigel on ice and seeded on pre-warmed 24-well cell culture plates; $500 \mu \mathrm{l}$ AdDF+++ media was added on the top of the Matrigel to each well.

\section{Cell culture}

Hec50 cells were kindly provided by Dr. Erlio Gurpide (New York University) [17] and grown in high-glucose Dulbecco's Modified Eagle Medium (DMEM; Gibco Corporation, USA) supplemented with 10\% fetal bovine serum. KLE cells were purchased from ATCC and grown in RPMI- 1640 medium supplemented with $10 \%$ fetal bovine serum. Human umbilical vascular endothelial cells (HUVEC) were purchased from ATCC and grown in EGMTM -2 MV Microvascular Endothelial Cell Growth Medium (2 BulletKit, Lonza, GA, USA). To ensure rigor and reproducibility, the identity of all cell lines was confirmed using the CODIS genotyping test (Cat. No. CL1003, Bio-Synthesis).

\section{Western blot}

Cells were collected and lysed with NP-40 lysis buffer with protease inhibitors. Lysates were analyzed for protein expression/phosphorylation as described previously $[18,19]$. The following antibodies were used at the indicated dilutions; all antibodies were purchased from Cell Signaling: anti-p-AKT-S473 (1:1000, \#4060), anti-AKT (1:1000, \#4685), anti-p-p44/42 MAPK (Erk1/2) -Thr202/Tyr204 (1:1000, \#4370), antip44/42 MAPK (Erk1/2) (1:1000, \#4695), anti-p-p38 MAPK-Thr180/Tyr182 (1:1000, \#9211), anti-p38 MAPK (1:1000, \#8690), anti-p-cdc2-Tyr15 (1:1000, \#4539), anti-cdc2 (1:1000, \#9116), anti-p-CDC25CSer216 (1:1000, \#4901), anti-CDC25C(1:1000, \#4688), anti-p-Histone H3-ser10 (1:1000, \#53348). 


\section{Cell viability assay}

Organoids: Viability of the tumor organoids following drug treatment was performed as previously described [16]. Briefly, patient-derived organoids were collected with organoid harvesting solution (Cultrex, USA), and then digested to single cells with TrypLE Express supplemented with $4 \mu 10 \mathrm{mg} / \mathrm{ml}$ DNAse I stock and $4 \mu \mathrm{l} 10 \mathrm{mM}$ Y-27632 stock. Single cells were suspended in AdDE+++ medium with $10 \%$ Matrigel and seeded at a density of 10,000 cells/well ( $50 \mu \mathrm{l} /$ well) in an ultra-low attachment 96 -well Ubottom white plate. After $24 \mathrm{hrs}$, cells were exposed to paclitaxel $(10 \mathrm{nM})$, bevacizumab $(1 \mu \mathrm{M})$, or cediranib $(1 \mu \mathrm{M})$ for $72 \mathrm{~h}$ at $37^{\circ} \mathrm{C}$. At the end of incubation, equal volume of CellTiter-Glo 3D reagent (Promega) was added to each well and incubated for $25 \mathrm{~min}$ at room temperature. The luminescence was measured using the Gen5 Microplate Reader (BioTek, Vermont, USA). All the tests were conducted in triplicate and data normalized to untreated control (set at 100\% viability).

Cell lines: Cell viability was determined by WST-1 assay as previously described [20]. Briefly, Hec50 and KLE cells were seeded into 96 -well plates (10,000 cells per well) for $24 \mathrm{hrs}$ and then cultured with increased concentrations of the drugs for an additional $72 \mathrm{hrs}$. Cell viability was evaluated using the cell proliferation reagent WST-1 (Roche, Germany) according to the manufacturer's protocol. The absorbance was measured with a micro-plate reader (Biorad). All the tests were conducted in triplicate and data normalized to untreated control (set at $100 \%$ viability).

\section{Cell cycle analysis}

Cell cycle analysis was performed by flow cytometry as described previously [18]. Equal number of cells were plated in $10 \mathrm{~cm}$ plates and treated with different drugs for $24 \mathrm{hrs}$ as for cell viability assays. Cell pellets were harvested and suspended separately in Krishan's solution ( $3.8 \mathrm{mM}$ sodium citrate, $0.014 \mathrm{mM}$ propidium iodide, $1 \% \mathrm{NP}-40$ and $2.0 \mathrm{mg} / \mathrm{ml}$ RNase A). Cell suspensions were analyzed using a FacScan Flow Cytometer (Becton, Dickinson and Company, San Jose, CA) and data were analyzed by CellQuest software version 3.3.

\section{Shedding assay}

HUVEC, Hec50, and KLE cells were grown to $70-80 \%$ confluence and serum-starved in Opti-MEM for one hour prior to transfection. Transfection of $1 \mu \mathrm{g}$ alkaline phosphatase (AP)-tagged transforming growth factor (TGF)-a were performed according to manufacturer's protocols using Lipofectamine2000 (Invitrogen, Carlsbad, CA). Cells were starved for at least four hours before the stimulation. Recombinant human vascular endothelial growth factor (VEGF-A) was obtained from R\&D Systems (Minneapolis, MN) and used at a concentration of $100 \mathrm{ng} / \mathrm{ml}$. The concentration of bevacizumab was $1 \mu \mathrm{g} / \mathrm{ml}$. PMA (phorbol-12-myristate-13-acetate) and the AP-tagged TGF-a plasmid have been previously published [21]. Evaluation of AP activity was determined by colorimetric assay as described previously [22]. Briefly, the ratio between the total AP activity in the supernatant and the total AP activity in the cell lysate plus supernatant was computed for normalization. The presented ratios reflect the relative proteolytic activity 
of a given sheddase toward the AP-tagged ligand TGF-a. No AP activity was detected in the conditioned media of untransfected cells.

\section{Phosphoproteomic microarray}

Hec50 cells were plated in $15 \mathrm{~cm}$ plates and treated with DMSO, $1 \mu \mathrm{M}$ bevacizumab or $1 \mu \mathrm{M}$ cediranib for $24 \mathrm{hrs}$. Cell pellets were collected and lysed with Kinexus Lysis Buffer with chemical cleavage. The microarray assay and data analysis were performed with Kinex ${ }^{\text {TM }}$ KAM-1325 Antibody Microarray Kit by Kinexus Bioinformatics Corporation. To qualify as a lead, the percent change from control (\%CFC) value should be at least $45 \%$ higher or lower with fluorescent signals that were at least 1,000 counts [23].

\section{Statistical analysis}

Data were analyzed using GraphPad Prism software. Statistical significance of differences was determined using one-way ANOVA with Sidak's post-hoc test or two-way ANOVA with Tukey's post-hoc test, as specified. All values are expressed as mean \pm standard deviation (SD) of at least three independent experiments unless otherwise indicated.

\section{Results}

\section{Tyrosine kinase receptor signaling pathways are downregulated by cediranib but not bevacizumab}

We first established the inhibitory potential of bevacizumab and cediranib on ligand-stimulated ERK activation in HUVEC cells by Western blot (Figure 1A). In contrast to robust inhibition of ERK phosphorylation at Thr202/Tyr204 by both bevacizumab and cediranib in HUVEC cells, the phosphorylation form of ERK displayed no significant induction with VEGF-A treatment and no obvious change with the addition of bevacizumab, suggesting that the intracellular signaling impact of VEGF-A is not robust in these tumor cells as compared to the known impact of VEGF-A on the vasculature of the surrounding tumor microenvironment [5].

Bevacizumab acts by selectively binding circulating VEGF, thereby inhibiting VEGFR1/2 activation [24]. Cediranib also inhibits VEGFR1/2/3 as well as PDGFRs and FGFR1 [5]. Previous studies have shown that activation of VEGFR2 by VEGF triggers a disintegrin and metalloprotease (ADAM) 17-dependent release of EGFR ligands such as TGF-a in a variety of different cells [25]. To monitor the effect of bevacizumab and cediranib on activation of ADAM17, we stimulated AP-TGF-a expressing cells with VEGF-A. PMA, a well-known activator of ADAM17-mediated shedding events served as a positive control [26, 27]. As anticipated, VEGF-A promoted a substantial increase in AP-TGF-a shedding in HUVEC cells, indicative of VEGFR2 activation (Figure 1B). This effect was blunted by both bevacizumab and cediranib. By contrast, VEGF-A did not significantly increase shedding of AP-TGF-a in Hec50 and KLE cells (Figure 1B). These data are in alignment with the lack of ERK phosphorylation in Hec50 and KLE cells in response to VEGFA. Similar to the Western blot results, cediranib decreased basal, unstimulated shedding of AP-TGF-a in all nolle

Loading [MathJax]/jax/output/CommonHTML/fonts/TeX/fontdata.js 


\section{Cediranib but not bevacizumab synergizes with chemotherapy}

Based on the differential responses of bevacizumab and cediranib in our cell-based assays, we next examined the impact of these agents on cell viability in endometrial cancer models. Studies were first performed in eight patient-derived organoid models of endometrial cancer (Supplemental Table S1). The models represent the spectrum of endometrial cancer, from early stage/grade endometrioid adenocarcinoma to stage IV serous adenocarcinoma.

We previously reported that the combination of tyrosine kinase inhibitors (TKIs) or anti-angiogenic TKIs with the chemotherapy paclitaxel induces massive cell death via mitotic catastrophe [18-20]. We therefore screened the endometrial cancer organoid models for sensitivity to paclitaxel alone or in combination with bevacizumab or cediranib (Figure 2). As compared to untreated control, six of the eight patientderived organoids exhibited a significant decrease in viability when treated with the paclitaxel, with a maximal decrease in viability of $57 \%$ by 72 hrs (Patient \#ONC-6099) (Figure 2A). Both cediranib and bevacizumab as single agents had no impact on cell viability. The decrease in viability of combinatorial regimens was calculated relative to paclitaxel as a single agent (Figure 2B). Cediranib but not bevacizumab synergized with paclitaxel, as evidenced by a decrease in viability when combined with paclitaxel as compared to paclitaxel alone (Figure 2B).

Studies were then extended to well-characterized cell models of advanced endometrial cancer with varying baseline sensitivity to paclitaxel $[19,20]$ (Figure 3 ). As in the organoid models, bevacizumab did not provide any additional cell killing when combined with paclitaxel (Figure 3A). Dose-response curves using either paclitaxel or cediranib in the presence of a set concentration of the opposing drug indicates synergy when the two agents are combined as compared to single-drug alone (Figure 3B, C). This trend was most pronounced in Hec50 cells, with no synergy observed in KLE cells treated with equivalent doses of the drugs (Figure 3B, C).

\section{The combination of cediranib but not bevacizumab with paclitaxel increases the percentage of cells in mitosis}

Flow cytometric measurements were performed to determine the effects of paclitaxel, cediranib, bevacizumab, and the combination treatment on cell cycle in Hec50 cells, which were more sensitive to the combination of cediranib and paclitaxel in Figure 3. Treatment with cediranib or bevacizumab alone had little effect on cell cycle distribution as compared to control treatment (Figure 4). Paclitaxel is a microtubule stabilizing agent and thus is most effective in mitosis ( $M$ phase of the cell cycle). As expected, treatment with paclitaxel alone resulted in a marked shift in cells to the G2/M phase. The combination of paclitaxel and cediranib produced a profound increase in the accumulation of cells in mitosis as assessed by the percentage of cells in G2/M by flow cytometry compared to paclitaxel alone (Figure 4B). Yet there was minimal change in the percentage of cells in $\mathrm{G} 2 / \mathrm{M}$ in bevacizumab+paclitaxeltreated cells (Figure 4A). These findings indicate that paclitaxel treatment in the presence of cediranib results in a significant enhancement of the $\mathrm{G} 2 / \mathrm{M}$ population by flow cytometry - the predominance of 
To better understand the mechanism of the mitotic cell death induction by paclitaxel and cediranib, we next examined the expression and post-translational modification of critical regulators of the $\mathrm{G} 2 / \mathrm{M}$ checkpoint including cdc2 and CDC25C. The effect of gefitinib, a tyrosine kinase inhibitor specific for EGFR, in combination with paclitaxel serves as a positive control based upon our previous work that gefitinib and paclitaxel promote premature entry to mitosis, especially in Hec50 cells that are devoid of functional p53 [19].

Treatment of Hec50 cells with cediranib in combination with paclitaxel decreased phosphorylation cdc2. De-phosphorylation of cdc2 is the final signaling step that opens the G2/M checkpoint, thereby allowing cells to enter mitosis. Cells that stop at G2/M have the potential to repair DNA prior to mitosis; however, when the checkpoint is abrogated as reflected by the dephosphorylation of cdc2, cells with damaged DNA enter mitosis and are more vulnerable to paclitaxel (Figure 5A). The active form of CDC25C, a protein phosphatase responsible for dephosphorylating cdc2 (abrogating the G2/M checkpoint), was significantly increased by this treatment regimen as demonstrated by a loss of phosphorylation at Ser216 and a slower migrating band in the total $\mathrm{CDC} 25 \mathrm{C}$ blot. These same signaling events were not observed with bevacizumab was combined with paclitaxel (Figure 5A), indicating a lack of G2/M checkpoint abrogation.

We also examined the effect of combinatorial treatment on KLE endometrial cancer cells, which we previously found to be resistant to paclitaxel+gefitinib [19]. Treatment with anti-angiogenic agents or gefitinib in combination with paclitaxel failed to override the G2/M cell cycle checkpoint, consistent with our previous findings.

To better understand why bevacizumab has no impact on cell survival or cell cycle progression in cancer cells, we performed a phosphoproteomic array using a panel of over 800 phosphorylation sites [23]. We detected similar trends in Akt and ERK/MAPK signaling and G2/M cell cycle checkpoints in response to bevacizumab or cediranib as single agents in Hec50 cells (Figure 5B). Changes in other cell cycle controllers included in the phosphoproteomic array are depicted in Figure 6A. Interestingly, bevacizumab as a single agent promoted more signaling events than cediranib, with only five changes shared between the two treatment groups (Figure 6B, C). Additionally, cediranib largely promoted decreased phosphorylation of signaling molecules, the expected therapeutic effect of a multi-TKI, whereas bevacizumab both increased and decreased phosphorylation events. We hypothesize that increased phosphorylation on pro-growth signaling molecules in response to bevacizumab treatment indicates a potential signal of developing cellular resistance.

\section{Discussion}

Angiogenesis plays a crucial role in tumor development and metastasis, and many cancer cells upregulate VEGF-A expression to promote angiogenesis. VEGF-A binds to VEGFR1 and VEGFR2, and it is the main stimulator of tumor growth and dissemination. Accordingly, many inhibitors of angiogenesis hava hoon toctod in clinical triale fnr a ranno of nannore with FDA approval for 11 agents that inhibit Loading [MathJax]/jax/output/CommonHTML/fonts/TeX/fontdata.js 
either VEGF ligands or receptors [28]. Bevacizumab, which has been approved for cervical and ovarian cancers, specifically binds to the VEGF-A protein and thereby inhibits vessel growth in the tumor. Indeed, our group has observed that higher expression levels of VEGF-A in tumor may be associated with improved outcomes when patients with advanced endometrial cancer were treated with bevacizumab. Cediranib is a tyrosine kinase inhibitor which targets VEGFR-1, -2, -3, PDGFR, and FGFR. It is thought to be effective in prevention of tumor progression, not only by inhibiting VEGFR-2 activity and angiogenesis, but also by concomitantly inhibiting VEGFR-3 activity and lymphangiogenesis.

While role of anti-angiogenic agents on tumor vascularization and endothelial cell growth been welldocumented, few studies have interrogated the impact of anti-angiogenic agents on the properties of tumor cells themselves. In the present study, our objective was to compare the impact of angiogenic inhibitors on endometrial cancer cells. First, we found that cancer cells were not significantly responsive to VEGF-A. Bevacizumab, a monoclonal antibody specifically raised against VEGF-A, had little impact on cell viability or cell cycle progression alone.

In addition, bevacizumab did not synergize with chemotherapy as we had previously found for other agents that target TKI signaling [18-20]. We show evidence that synergy was related to the impact on cell cycle when comparing bevacizumab, with its narrow range of activity, to a multi-targeted anti-angiogenic TKI such as cediranib. Thus, we propose that the ability of cediranib, but not bevacizumab, to inhibit multiple kinases and to de-phosphorylate the G2/M gatekeeper cdc2, results in G2/M checkpoint abrogation, premature entry of tumor cells with damaged DNA into mitosis, and cell death through mitotic catastrophe. The significant enhancement of the percent of cells in G2/M when cells are treated with cediranib and paclitaxel signifies this as a mechanism of synergy.

The phosphoproteomic array results reported are valuable as a readout of the numerous signaling events in response to bevacizumab and cediranib treatment at a single time point, $24 \mathrm{hrs}$. The inhibition of phosphorylation of multiple targets related to cediranib activity likely underlies its therapeutic effects as a tyrosine kinase inhibitor. In contrast, we found the phosphorylation events were more often induced after bevacizumab treatment. Enhanced phosphorylation, most commonly associated with signaling activation and proliferative signals, may suggest that cells treated with bevacizumab are able to induce resistance pathways by $24 \mathrm{hrs}$. Knowing these potential resistance phosphorylation events may be a powerful tool. They are interesting to consider and analyze in subsequent studies as they shed light on therapeutic agents that could block the resistance phosphorylation events when added to bevacizumab.

While no direct comparison of efficacy between cediranib and bevacizumab has been reported, we predicted cediranib would have greater benefit due to the additional blockade of all VEGFR isoforms as well as PDGF and FGF receptors. Isoforms of PDGFR and FGFR are expressed in endometrial tumors [29, 30], with FGFR2 mutations occurring in 13\% of endometrial cancer cases [31]. We found that cediranib, as a multi-TKI inhibitor, had greater therapeutic effects, including blunting baseline ERK activation, synergizing with paclitaxel in organoid models and cell lines and the anticipated abrogation of the G2/M cell rvele rherknnint

Loading [MathJax]/jax/output/CommonHTML/fonts/TeX/fontdata.js

Page $10 / 23$ 
Findings from this preliminary study in preclinical models should be expanded to determine the mechanisms of differential sensitivity at the molecular level to cediranib, as evidenced by the lack of synergy when cediranib was combined with paclitaxel in KLE endometrial cancer cells as well as some organoid models. We originally hypothesized that the mutations in p53, a well-established controller of the G1/S and G2/M cell cycle checkpoints, would predict for enhanced synergy. This hypothesis follows our recently published translational study of G0G-86P in which patients with mutations in TP53 had significantly improved outcomes when bevacizumab was combined with chemotherapy as compared to other experimental agents (Leslie, accepted for publication). However, the majority of endometrial organoid models used in this study had WT p53, precluding a definitive analysis of the role of p53 in sensitivity.

\section{Conclusions}

The standard of care for endometrial cancer has not changed beyond chemotherapy, incidence is on the rise due to the obesity epidemic, and outcomes are worse now than in the 1970s. The data presented in this report are designed to identify agents that should be advanced into clinical trials to improve outcome for women with endometrial cancer. Based on our findings, we put forth that cediranib should be investigated in future clinical trials in endometrial cancer in the upfront setting in combination with chemotherapy. Specifically, our data suggest that the anti-angiogenic agent cediranib may have additional advantages over bevacizumab as an anti-cancer therapeutic due to its dual effects on tumor cells and the vasculature. Our use of endometrial tumor tissue cultured as functional 3D organoids provides highly translational information on the efficacy of anti-angiogenic agents in tumor cells. These data set the stage for future clinical trials to evaluate cediranib in combination with chemotherapy as a treatment for women with endometrial cancer.

\section{Abbreviations}

ADAM: a disintegrin and metalloprotease

AdDF+++ media: Advanced DMEM-F12 media with 1X Glutamax,10mM HEPES

AP: alkaline phosphatase

Bev: bevacizumab

Ced: cediranib

CT: control

FGFR: fibroblast growth factor receptor

GOG: Gynecologic Oncology Group 
HUVEC: human umbilical vascular endothelial cells

IRB: institutional review board

M: mitosis

Pan: total protein expression

PDGFR: platelet-derived growth factor receptor

PMA: phorbol-12-myristate-13-acetate

SD: standard deviation

TGF-a: transforming growth factor-a

TKI: tyrosine kinase inhibitors

VEGF-A: vascular endothelial growth factor-A

VEGFR: VEGF receptor

\%CFC: percent change from control

\section{Declarations}

Ethics approval and consent to participate: This study was approved by the University of lowa Institutional Review Board (IRB, \# 201809807).

Consent for publication: Not applicable.

Availability of data and materials: All data generated or analyzed during this study are included in this published article.

Competing interests: KWT is a co-founder of Immortagen, Inc. All other authors declare that they have no competing interests.

Funding: This study was funded by the National Institutes of Health (R01CA099908 to KKL), the Department of Defense Ovarian Cancer Research Program (OC190352 to KKL), and the American Cancer Society (ACS-IRG-15-176-41 and ACS-IRG-18-165-43 to TM). Research reported in this publication was also supported by the National Center For Advancing Translational Sciences of the National Institutes of Health under Award Number UL1TR002537 and the National Cancer Institute of the National Institutes of Health under Award Number P30CA086862. The funders had no role in the design of the study and collection, analysis and interpretation of the data or in writing of the manuscript. The content is solely the rocnnncihility of tho authnre and dnoc not nonoccarily ronresent the official views of the funders. 
Authors' contributions: JB, KWT and KKL conceived of the study. JB, AMN, DAS, KLC, KWT and KKL coordinated tumor specimen collection for organoid culture models. JB, AMN generated organoid models. JB, EJD, YZ characterized organoid models. JB performed drug response experiments in cell lines and organoid models. AMN, HAL performed chart review for clinical characteristics. JB, GD, TM, KWT, KKL analyzed data and/or performed statistical analyses. JB performed Western blots and/or phosphoproteomic analysis. GD performed AP-TGF-a shedding assays. YZ performed flow cytometry. All authors read and approved the final manuscript.

Acknowledgements: None.

\section{References}

1. Cancer Facts and Figures 2020 [https://www.cancer.org/content/dam/cancer-org/research/cancerfacts-and-statistics/annual-cancer-facts-and-figures/2020/cancer-facts-and-figures-2020.pdf]

2. Sheikh MA, Althouse AD, Freese KE, Soisson S, Edwards RP, Welburn S, Sukumvanich P, Comerci J, Kelley J, LaPorte RE et al: USA endometrial cancer projections to 2030: should we be concerned? Future Oncol 2014, 10(16):2561-2568.

3. Aghajanian C, Sill MW, Darcy KM, Greer B, McMeekin DS, Rose PG, Rotmensch J, Barnes MN, Hanjani P, Leslie KK: Phase II trial of bevacizumab in recurrent or persistent endometrial cancer: a Gynecologic Oncology Group study. J Clin Oncol 2011, 29(16):2259-2265.

4. Alvarez EA, Brady WE, Walker JL, Rotmensch J, Zhou XC, Kendrick JE, Yamada SD, Schilder JM, Cohn $\mathrm{DE}$, Harrison $\mathrm{CR}$ et al: Phase II trial of combination bevacizumab and temsirolimus in the treatment of recurrent or persistent endometrial carcinoma: a Gynecologic Oncology Group study. Gynecol Oncol 2013, 129(1):22-27.

5. Wedge SR, Kendrew J, Hennequin LF, Valentine PJ, Barry ST, Brave SR, Smith NR, James NH, Dukes $\mathrm{M}$, Curwen JO et al: AZD2171: a highly potent, orally bioavailable, vascular endothelial growth factor receptor-2 tyrosine kinase inhibitor for the treatment of cancer. Cancer Res 2005, 65(10):4389-4400.

6. Brave SR, Ratcliffe K, Wilson Z, James NH, Ashton S, Wainwright A, Kendrew J, Dudley P, Broadbent $\mathrm{N}$, Sproat $\mathrm{G}$ et al: Assessing the activity of cediranib, a VEGFR-2/3 tyrosine kinase inhibitor, against VEGFR-1 and members of the structurally related PDGFR family. Mol Cancer Ther 2011, 10(5):861873.

7. Bender D, Sill MW, Lankes HA, Reyes HD, Darus CJ, Delmore JE, Rotmensch J, Gray HJ, Mannel RS, Schilder $\mathrm{JM}$ et al: A phase Il evaluation of cediranib in the treatment of recurrent or persistent endometrial cancer: An NRG Oncology/Gynecologic Oncology Group study. Gynecol Oncol 2015, 138(3):507-512.

8. Dizon DS, Sill MW, Schilder JM, McGonigle KF, Rahman Z, Miller DS, Mutch DG, Leslie KK: A phase II evaluation of nintedanib (BIBF-1120) in the treatment of recurrent or persistent endometrial cancer: An NRG Oncology/Gynecologic Oncology Group Study. Gynecol Oncol 2014, 135(3):441-445. 
9. Powell MA, Sill MW, Goodfellow PJ, Benbrook DM, Lankes HA, Leslie KK, Jeske Y, Mannel RS, Spillman MA, Lee PS et al: A phase Il trial of brivanib in recurrent or persistent endometrial cancer: an NRG Oncology/Gynecologic Oncology Group Study. Gynecol Oncol 2014, 135(1):38-43.

10. Nimeiri HS, Oza AM, Morgan RJ, Huo D, Elit L, Knost JA, Wade JL, 3rd, Agamah E, Vokes EE, Fleming GF: A phase II study of sorafenib in advanced uterine carcinoma/carcinosarcoma: a trial of the Chicago, PMH, and California Phase II Consortia. Gynecol Oncol 2010, 117(1):37-40.

11. Coleman RL, Sill MW, Lankes HA, Fader AN, Finkler NJ, Hoffman JS, Rose PG, Sutton GP, Drescher CW, McMeekin DS et al: A phase Il evaluation of aflibercept in the treatment of recurrent or persistent endometrial cancer: a Gynecologic Oncology Group study. Gynecol Oncol 2012, 127(3):538-543.

12. Aghajanian C, Filiaci V, Dizon DS, Carlson JW, Powell MA, Secord AA, Tewari KS, Bender DP, O'Malley DM, Stuckey A et al: A phase Il study of frontline paclitaxel/carboplatin/bevacizumab, paclitaxel/carboplatin/temsirolimus, or ixabepilone/carboplatin/bevacizumab in advanced/recurrent endometrial cancer. Gynecol Oncol 2018, 150(2):274-281.

13. Kamat AA, Merritt WM, Coffey D, Lin YG, Patel PR, Broaddus R, Nugent E, Han LY, Landen CN, Jr., Spannuth WA et al: Clinical and biological significance of vascular endothelial growth factor in endometrial cancer. Clin Cancer Res 2007, 13(24):7487-7495.

14. Davies S, Dai D, Pickett G, Thiel KW, Korovkina VP, Leslie KK: Effects of bevacizumab in mouse model of endometrial cancer: Defining the molecular basis for resistance. Oncol Rep 2011, 25(3):855-862.

15. Decio A, Cesca M, Bizzaro F, Porcu L, Bettolini R, Ubezio P, Taraboletti G, Belotti D, Giavazzi R: Cediranib combined with chemotherapy reduces tumor dissemination and prolongs the survival of mice bearing patient-derived ovarian cancer xenografts with different responsiveness to cisplatin. Clin Exp Metastasis 2015, 32(7):647-658.

16. Bi J, Thiel KW, Litman JM, Zhang Y, Devor EJ, Newtson AM, Schnieders MJ, Gonzalez Bosquet J, Leslie KK: Characterization of a TP53 somatic variant of unknown function from an ovarian cancer patient using organoid culture and computational modeling. Clin Obstet Gynecol 2020, 63(1):109119.

17. Devor EJ, Gonzalez-Bosquet J, Thiel KW, Leslie KK: Genomic characterization of five commonly used endometrial cancer cell lines. Int J Oncol 2020, 57(6):1348-1357.

18. Meng X, Dizon DS, Yang S, Wang X, Zhu D, Thiel KW, Leslie KK: Strategies for molecularly enhanced chemotherapy to achieve synthetic lethality in endometrial tumors with mutant p53. Obstet Gynecol Int 2013, 2013:828165.

19. Meng X, Laidler LL, Kosmacek EA, Yang S, Xiong Z, Zhu D, Wang X, Dai D, Zhang Y, Brachova P et al: Induction of mitotic cell death by overriding $\mathrm{G} 2 / \mathrm{M}$ checkpoint in endometrial cancer cells with nonfunctional p53. Gynecol Oncol 2013, 128(3):461-469.

20. Ebeid K, Meng X, Thiel KW, Do AV, Geary SM, Morris AS, Pham EL, Wongrakpanich A, Chhonker YS, Murry DJ et al: Synthetically lethal nanoparticles for treatment of endometrial cancer. Nat Nanotechnol 2018, 13(1):72-81. 
21. Sahin U, Weskamp G, Kelly K, Zhou HM, Higashiyama S, Peschon J, Hartmann D, Saftig P, Blobel CP: Distinct roles for ADAM10 and ADAM17 in ectodomain shedding of six EGFR ligands. J Cell Biol 2004, 164(5):769-779.

22. Maretzky T, Yang G, Ouerfelli O, Overall CM, Worpenberg S, Hassiepen U, Eder J, Blobel CP: Characterization of the catalytic activity of the membrane-anchored metalloproteinase ADAM15 in cell-based assays. Biochem J 2009, 420(1):105-113.

23. Zhang H, Shi X, Pelech S: Monitoring Protein Kinase Expression and Phosphorylation in Cell Lysates with Antibody Microarrays. Methods Mol Biol 2016, 1360:107-122.

24. Kazazi-Hyseni F, Beijnen JH, Schellens JH: Bevacizumab. Oncologist 2010, 15(8):819-825.

25. Swendeman S, Mendelson K, Weskamp G, Horiuchi K, Deutsch U, Scherle P, Hooper A, Rafii S, Blobel CP: VEGF-A stimulates ADAM17-dependent shedding of VEGFR2 and crosstalk between VEGFR2 and ERK signaling. Circ Res 2008, 103(9):916-918.

26. Horiuchi K, Le Gall S, Schulte M, Yamaguchi T, Reiss K, Murphy G, Toyama Y, Hartmann D, Saftig P, Blobel CP: Substrate selectivity of epidermal growth factor-receptor ligand sheddases and their regulation by phorbol esters and calcium influx. Molecular biology of the cel/ 2007, 18(1):176-188.

27. Le Gall SM, Bobe P, Reiss K, Horiuchi K, Niu XD, Lundell D, Gibb DR, Conrad D, Saftig P, Blobel CP: ADAMs 10 and 17 represent differentially regulated components of a general shedding machinery for membrane proteins such as transforming growth factor alpha, L-selectin, and tumor necrosis factor alpha. Molecular biology of the cell 2009, 20(6):1785-1794.

28. Mukherjee A, Madamsetty VS, Paul MK, Mukherjee S: Recent Advancements of Nanomedicine towards Antiangiogenic Therapy in Cancer. Int J Mol Sci 2020, 21(2).

29. Roh JW, Huang J, Hu W, Yang X, Jennings NB, Sehgal V, Sohn BH, Han HD, Lee SJ, Thanapprapasr D et al: Biologic effects of platelet-derived growth factor receptor alpha blockade in uterine cancer. Clin Cancer Res 2014, 20(10):2740-2750.

30. Lee PS, Secord AA: Targeting molecular pathways in endometrial cancer: a focus on the FGFR pathway. Cancer Treat Rev 2014, 40(4):507-512.

31. Helsten T, Elkin S, Arthur E, Tomson BN, Carter J, Kurzrock R: The FGFR Landscape in Cancer: Analysis of 4,853 Tumors by Next-Generation Sequencing. Clin Cancer Res 2016, 22(1):259-267.

\section{Figures}


A
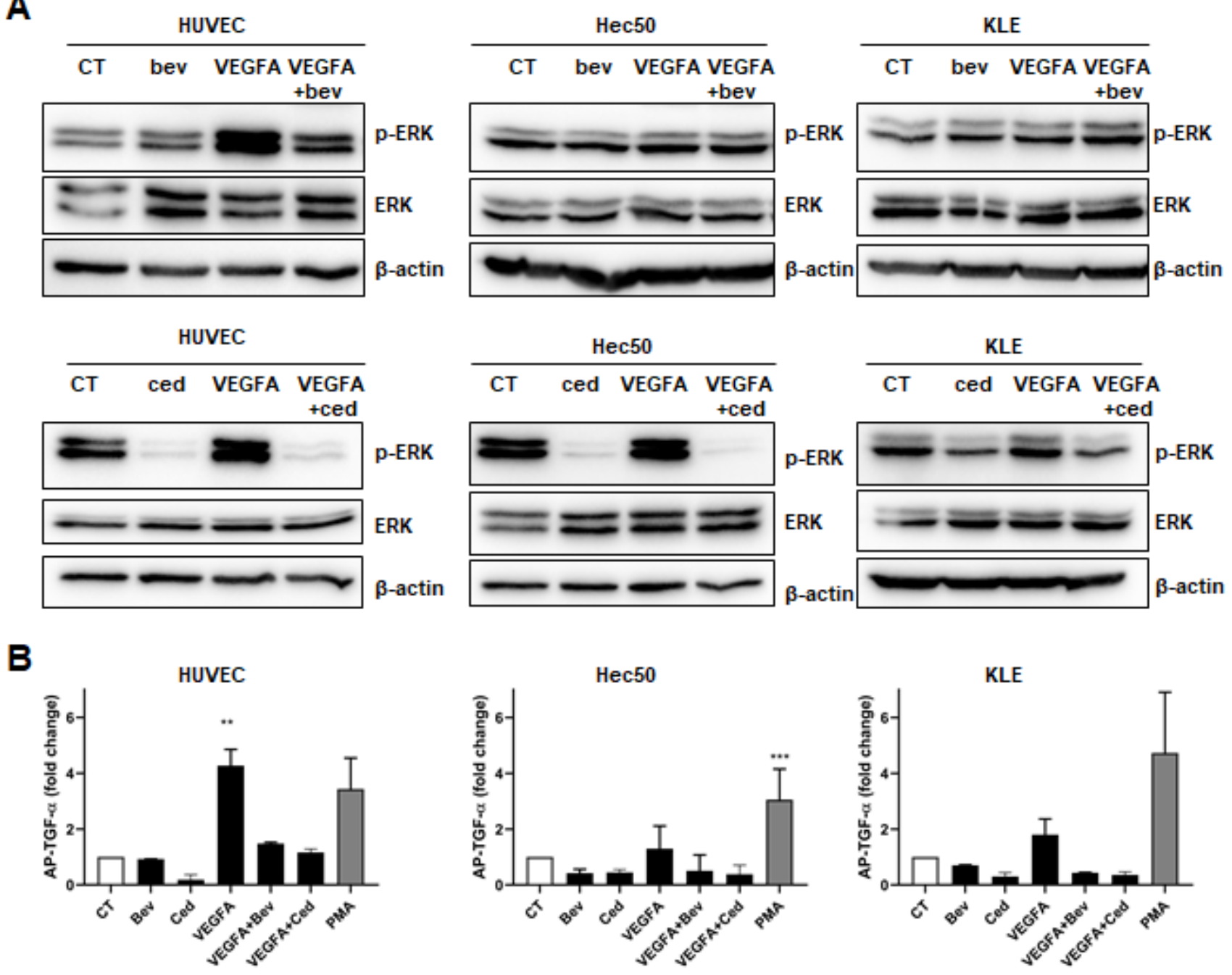

Figure 1

Impact of bevacizumab and cediranib on VEGFR signaling endothelial cells and endometrial cancer cells. (A) HUVEC, Hec50 and KLE cells were treated with vehicle control (CT), $1 \mu \mathrm{M}$ bevacizumab (Bev), 100 $\mathrm{ng} / \mathrm{ml}$ VEGF-A, or $1 \mu \mathrm{M}$ cediranib (Ced) for $1 \mathrm{hr}$, followed by assessment of ERK1/2 phosphorylation at Thr202/Tyr204 or total ERK expression by Western blotting. $\beta$-actin: loading control. (B) Cells were transfected with the alkaline phosphatase (AP)-tagged ADAM17 substrate TGF- $a$, and treated as in (A) for $1 \mathrm{hr}$. The change in soluble AP-TGF- $a$ was assessed and presented as fold change compared to CT. PMA $(25 \mathrm{ng} / \mathrm{ml})$ served as a positive control for induction of AP-TGF-a shedding. ${ }^{\star \star} p<0.01 ;{ }^{* \star \star} p<0.001 \mathrm{vs}$. CT by one-way ANOVA with Tukey's multiple comparisons test. 

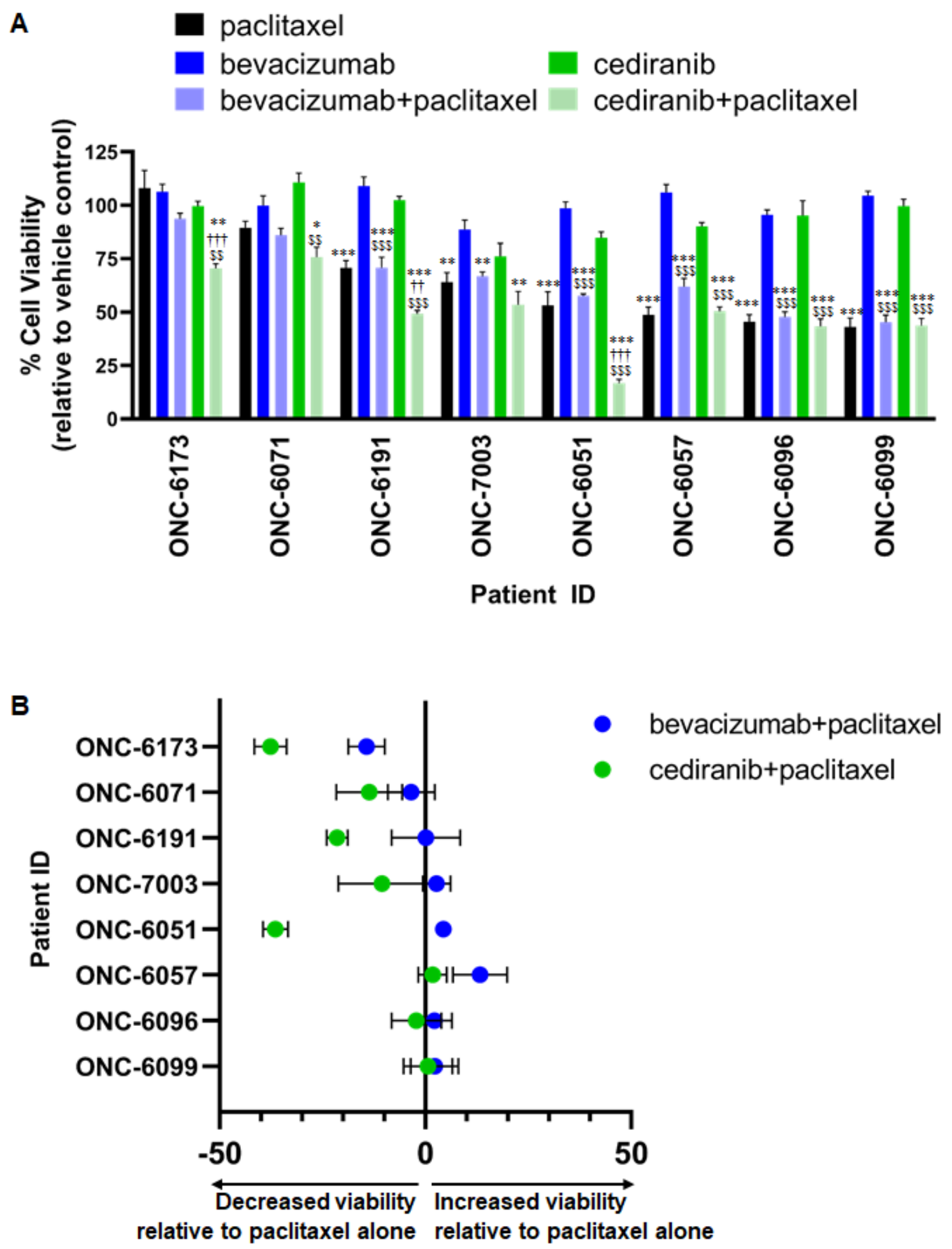

Figure 2

Effect of cediranib and bevacizumab on sensitivity to paclitaxel in patient-derived organoid cultures of primary endometrial tumors. Organoid cultures were treated with $10 \mathrm{nM}$ paclitaxel, $1 \mu \mathrm{M}$ bevacizumab, 1 $\mu \mathrm{M}$ cediranib, or the combination of paclitaxel with bevacizumab or cediranib for $72 \mathrm{hrs}$, followed by assessment of cell viability. (A) Data were calculated the percent (\%) cell viability as compared to vehicle 
viability with the combination of paclitaxel with either bevacizumab or cediranib was calculated relative to paclitaxel alone. ${ }^{*} p<0.05, * \star p<0.01, * \star \star p<0.001$ vs. control; $+\dagger p<0.01,+\dagger \dagger p<0.001$ vs. paclitaxel alone;

$$
p<0.01 \text {, }
$$

$\$ p<0.001$ vs. anti-angiogenic agent alone (bevacizumab for bevacizumab+paclitaxel or cediranib for cediranib+paclitaxel treated samples) by ordinary one-way ANOVA with Tukey's multiple comparisons test.

A

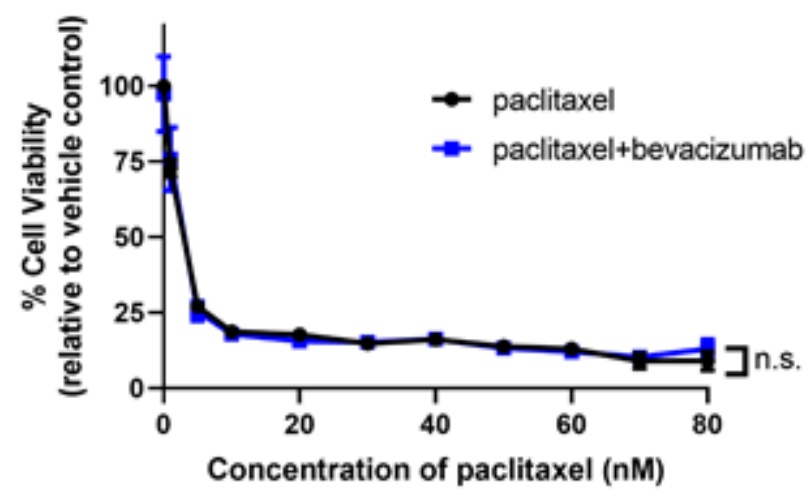

B

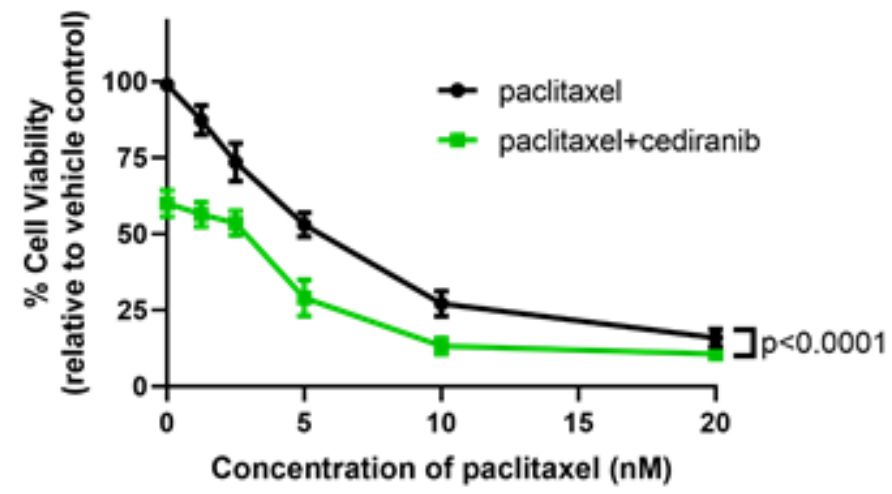

C

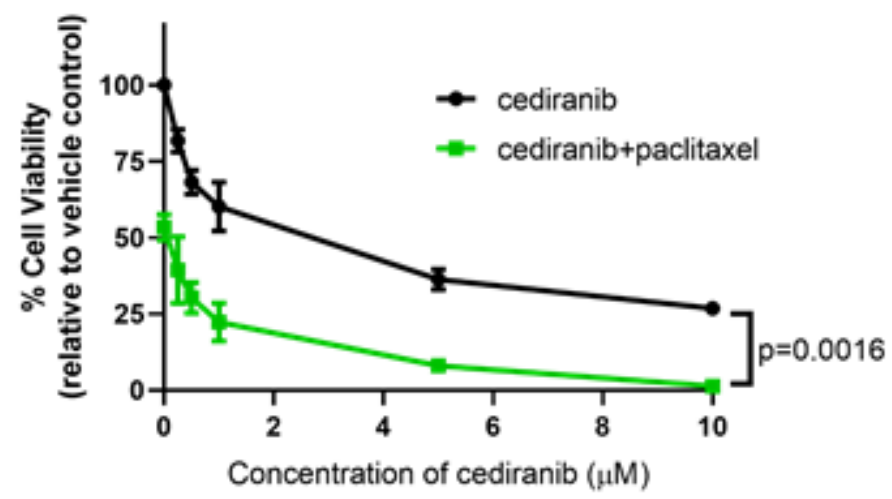

KLE

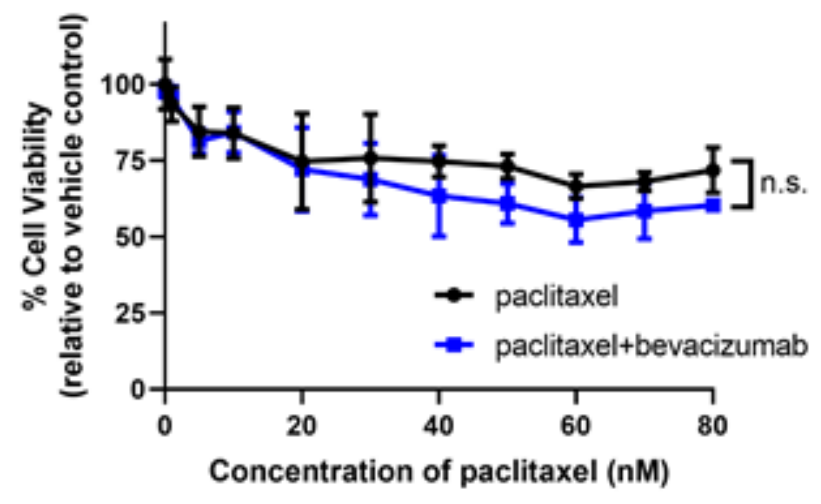

KLE

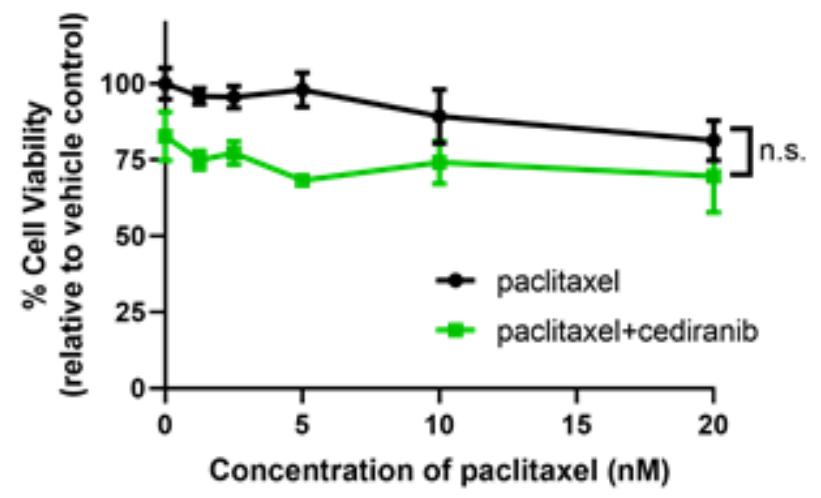

KLE

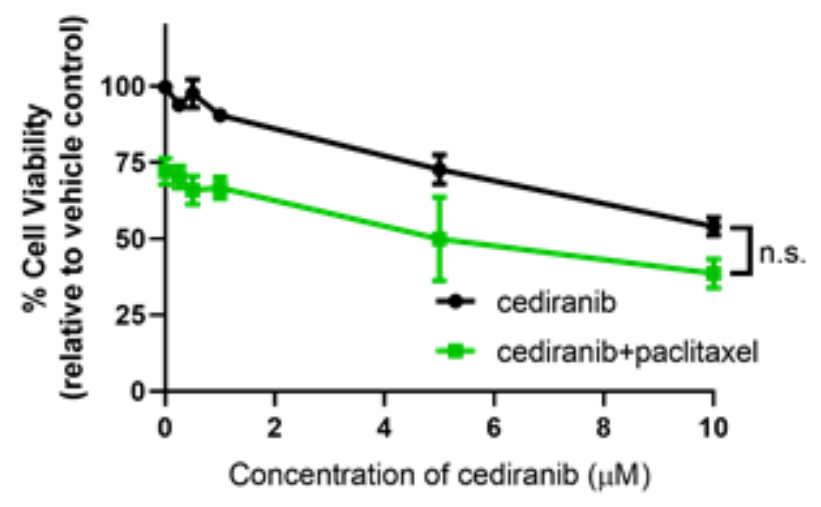




\section{Figure 3}

Cediranib but not bevacizumab increases sensitivity to paclitaxel in Hec50 endometrial cancer cells. (A) Hec50 (left) or KLE cells (right) were treated with increasing concentrations of paclitaxel in the absence or presence of $1 \mu \mathrm{M}$ bevacizumab for $72 \mathrm{~h}$; cell viability was determined using WST-1 assay relative to untreated control. (B) Hec50 (left) or KLE cells (right) were treated with increasing concentrations of paclitaxel in the absence or presence of $1 \mu \mathrm{M}$ cediranib for $72 \mathrm{hrs}$; cell viability was determined using WST-1 assay. (C) Hec50 (left) or KLE cells (right) were treated with increasing concentrations of cediranib in the absence or presence of $5 \mathrm{nM}$ paclitaxel for $72 \mathrm{hrs;}$ cell viability was determined using WST-1 assay. Statistical significance was assessed by two-way ANOVA with Sidak's post-hoc test.
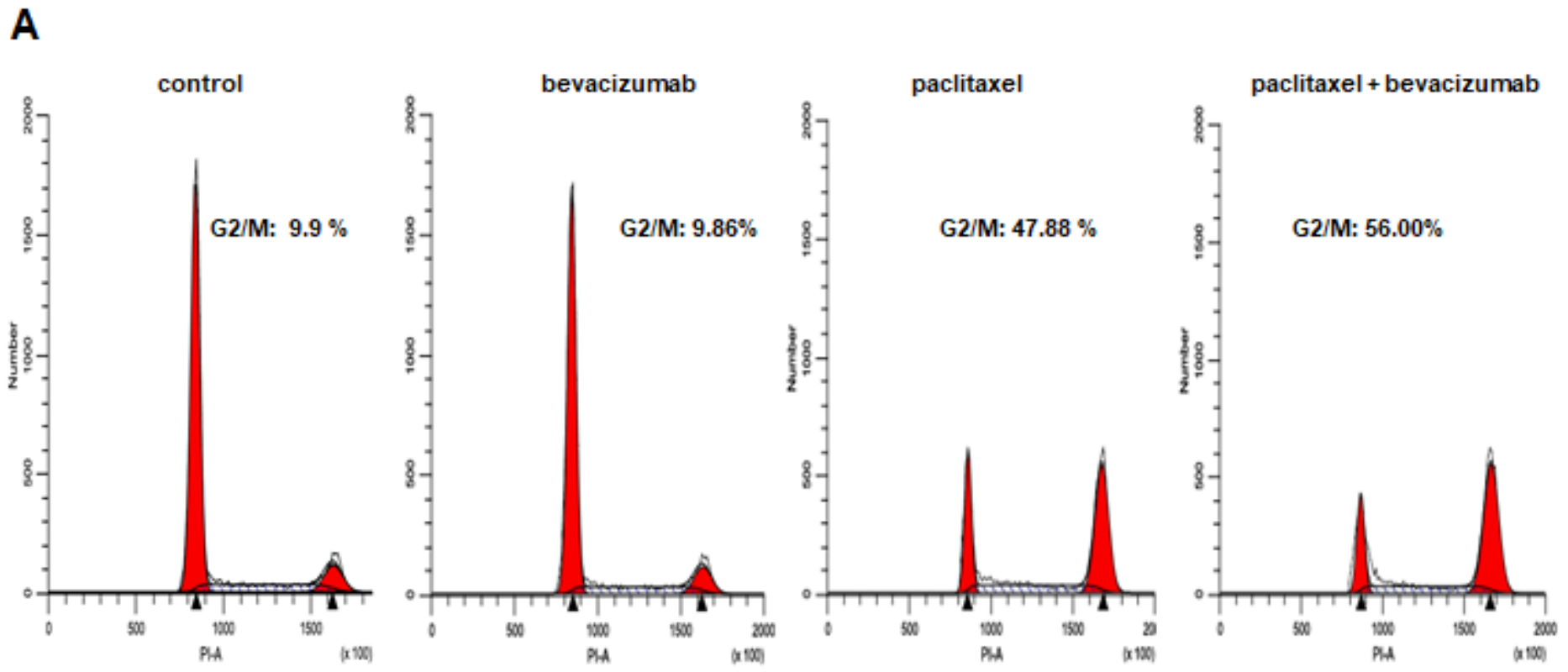

B
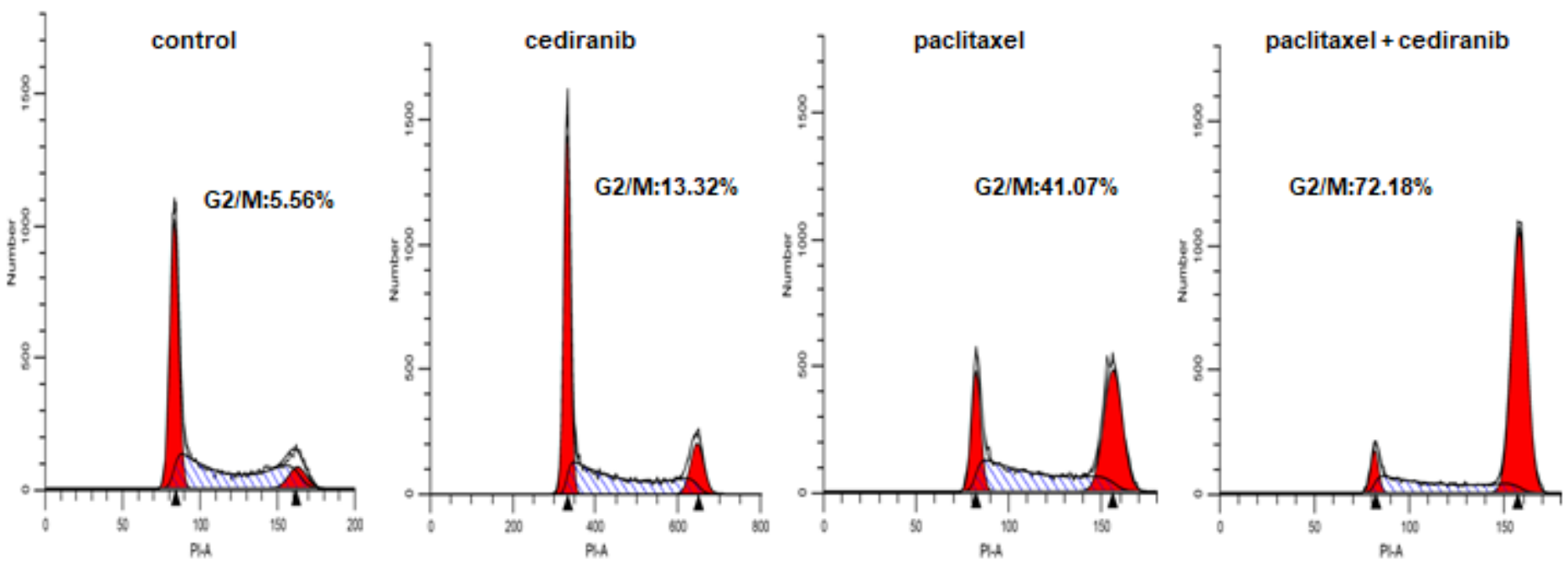

Figure 4

Comparison of the effect of cediranib and bevacizumab on cell cycle distribution in Hec50 cells treated with baclitaxel. (A) Cell cvcle distribution in Hec50 cells treated with DMSO (Control), $14 \mathrm{nM}$ paclitaxel, 1 Loading [MathJax]/jax/output/CommonHTML/fonts/TeX/fontdata.js 
$\mu \mathrm{M}$ bevacizumab, or a combination of paclitaxel and $1 \mu \mathrm{M}$ bevacizumab for $24 \mathrm{hrs}$. (B) Cell cycle distribution for Hec50 cells treated with vehicle (DMSO), $14 \mathrm{nM}$ paclitaxel, $1 \mu \mathrm{M}$ cediranib, or a combination of $14 \mathrm{nM}$ paclitaxel and $1 \mu \mathrm{M}$ cediranib. Insets denote the percentage of cells in $\mathrm{G} 2 / \mathrm{M}$ phase of the cell cycle.

A

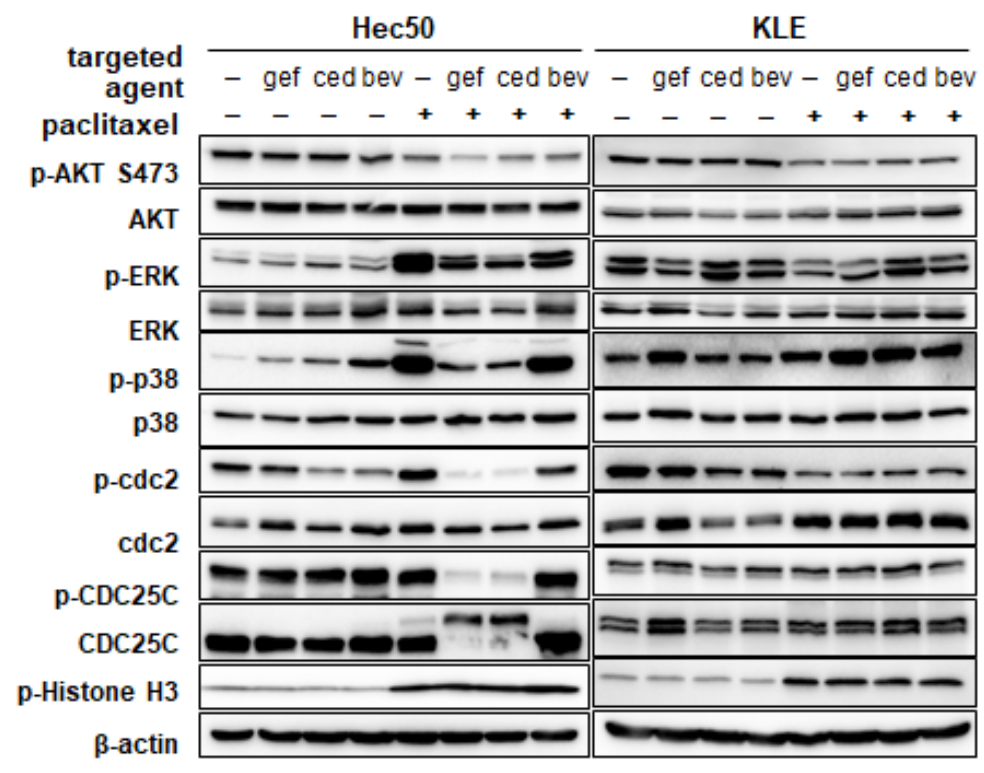

B

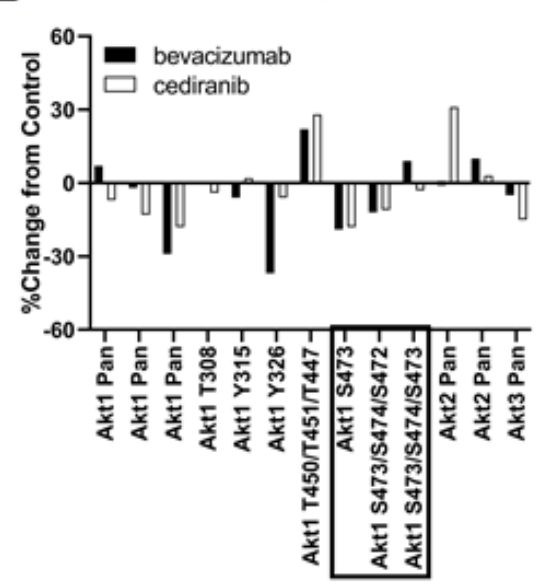

p38 MAPK

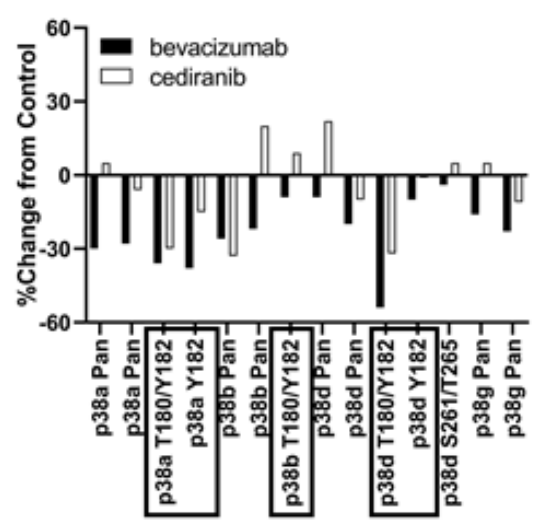

ERK

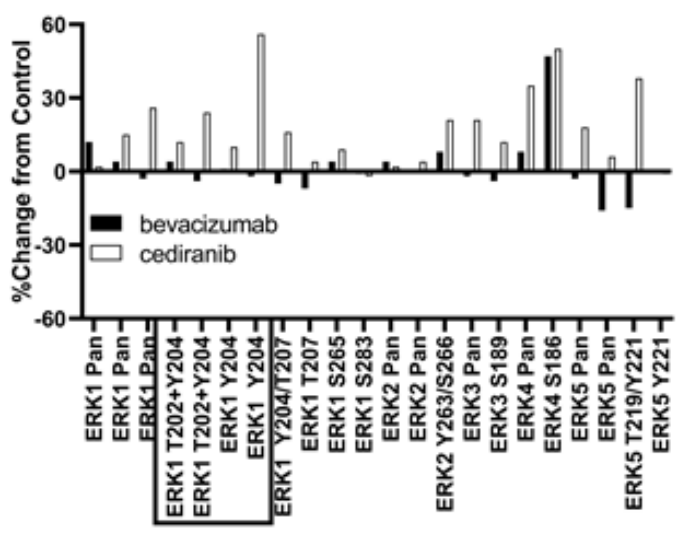

cdc2

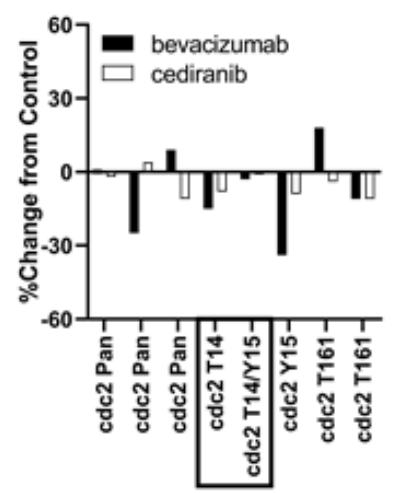

Histone $\mathrm{H} 3$

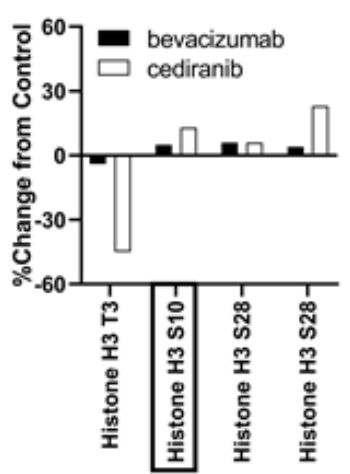

Figure 5 
Molecular effects of anti-angiogenic agents on G2/M cell cycle controllers in endometrial cancer cell models. (A) Hec50 (left) or KLE cells (right) were treated with the indicated agents either alone or in combination with paclitaxel for $24 \mathrm{hrs}$, followed by assessment of cell cycle controllers by Western blotting. Drug concentrations: $10 \mu \mathrm{M}$ gefitinib, $1 \mu \mathrm{M}$ cediranib, $1 \mu \mathrm{M}$ bevacizumab, $14 \mathrm{nM}$ paclitaxel. (B) Expression or phosphorylation of indicated proteins was assessed by Kinex ${ }^{\mathrm{TM}} \mathrm{KAM}-1325$

Phosphproteomic Antibody Microarray in Hec50 cells treated with $1 \mu \mathrm{M}$ bevacizumab or $1 \mu \mathrm{M}$ cediranib for $24 \mathrm{hrs}$. Data are calculated as the percent change from control (\%CFC). Phosphosites corresponding to those queried in $(A)$ are indicated with boxes. Pan: antibody total protein expression. 
A

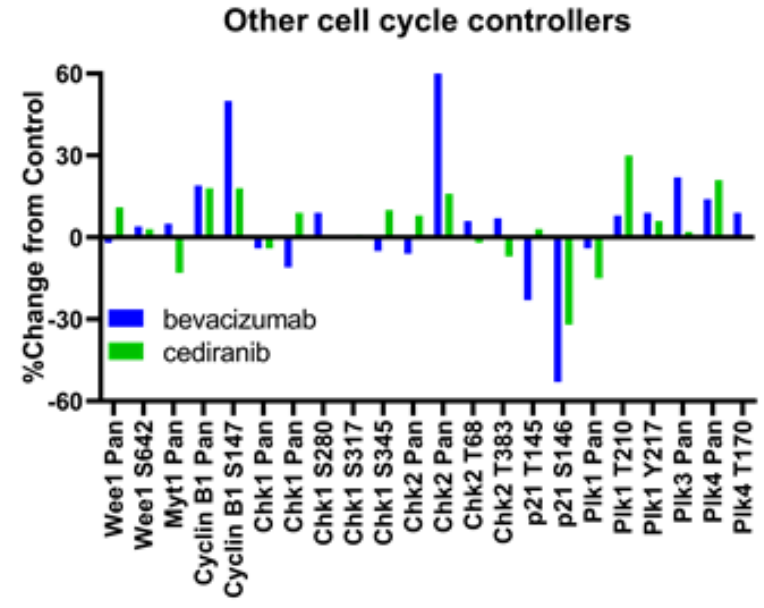

B

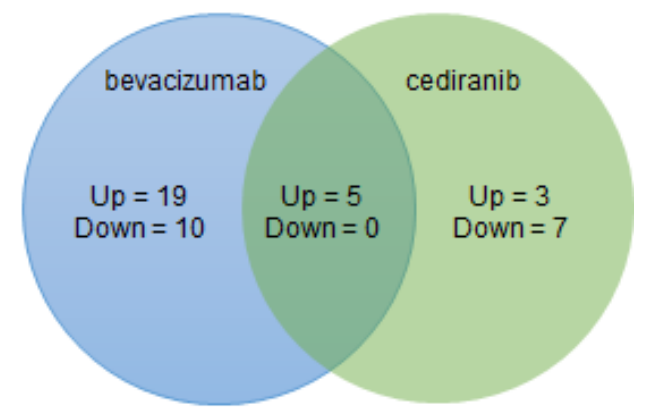

C

\begin{tabular}{|l|c|c|c|}
\hline \multirow{2}{*}{ Target Name } & \multirow{2}{*}{ Phospho-site } & bevacizumab & cediranib \\
\cline { 3 - 4 } & & $\%$ CFC & $\%$ CFC \\
\hline Abl2 (Arg) & Y439 & -56 & -34 \\
\hline ACC1 (ACACA) & S78+S80 & -47 & -31 \\
\hline ACC1 (ACACA) & S29 & -51 & -32 \\
\hline AurKB (Aurora B) & Pan-specific & 85 & 59 \\
\hline BRCA1 & S1423 & 871 & 242 \\
\hline Caveolin 2 & Pan-specific & 139 & -12 \\
\hline Cbl & Y700 & 156 & 75 \\
\hline elF4E & Pan-specific & -26 & 59 \\
\hline EphB2 & Y780 & -14 & 57 \\
\hline EphB3 & Y600 & -15 & 59 \\
\hline FAK (PTK2) & Y576+Y577 & 52 & 13 \\
\hline GFAP & Pan-specific & 898 & 1226 \\
\hline GSK3b & T275+T277 & 45 & 56 \\
\hline GSK3b & S9 & 48 & 44 \\
\hline MAT1A & T341 & 117 & 11 \\
\hline MEF2A & T108 & 128 & 38 \\
\hline MEF2C & S396 & 49 & 10 \\
\hline NuaK1 (ARK5)/Nuak2 & T211 & -36 & -53 \\
\hline P38d MAPK (MAPK13) & T180+Y182 & -54 & -32 \\
\hline p70S6K & T252 & 93 & -14 \\
\hline P70S6K & Pan-specific & -46 & -21 \\
\hline PFN1 & Y129 & -64 & -24 \\
\hline PKD3 (PRKCN) & Pan-specific & 71 & 65 \\
\hline PRKACA/B (PKA, PKACA/B) & T196+T198 & 76 & 65 \\
\hline PTPN1 (PTP1B) & S50 & 1 & 44 \\
\hline Raf1 (RafC) & S296 & 46 & 4 \\
\hline Raf1 (RafC) & S621 & -6 & 52 \\
\hline RelB & Pan-specific & 94 & 97 \\
\hline SrC & Y419 & -89 & -2 \\
\hline Syk & Y525+Y526 & 4 & 54 \\
\hline Syk & Y352 & -12 & 73 \\
\hline TA03 (JIK, TA0K3) & Pan-specific & 12 & 46 \\
\hline TRII128 (TIF1B) & S473 & -22 & 54 \\
\hline YAP1 & & 50 & 2 \\
\hline \hline
\end{tabular}

bevacizumab \& cediranib bevacizumab only cediranib only

\section{Figure 6}

Bevacizumab regulates more signaling events than cediranib in endometrial cancer cells. Signaling events in response to single-agent bevacizumab or cediranib were analyzed by Kinex ${ }^{\mathrm{TM}} \mathrm{KAM}-1325$ Phosphproteomic Antibody Microarray after treatment of Hec50 cells with $1 \mu \mathrm{M}$ bevacizumab or $1 \mu \mathrm{M}$ cediranib for 24 hrs. (A) Depiction of changes in select cell cycle controllers. Data are calculated as the 
candidates in response to either bevacizumab or cediranib. Overlap indicates signaling events that were shared between the two treatment groups. Up = increased expression/phosphorylation; down = decreased expression/phosphorylation. (C) Table of all lead candidates identified based on the \%CFC [23]. Negative \%CFC indicates a decrease as compared to control. Full results are provided as Supplemental Table S2.

\section{Supplementary Files}

This is a list of supplementary files associated with this preprint. Click to download.

- SupplementalTableS1.docx

- SupplementalTableS2Rawdataforphosphoproteomicarray.xlsx 